\title{
Influence of molecular design on biodistribution and targeting properties of an Affibody-fused HER2-recognising anticancer toxin
}

\author{
MOHAMED ALTAI $^{1 *}$, HAO LIU $^{2 *}$, ANNA ORLOVA $^{3}$, VLADIMIR TOLMACHEV $^{1}$ and TORBJÖRN GRÄSLUND ${ }^{2}$ \\ ${ }^{1}$ Institute of Immunology, Genetic and Pathology, Uppsala University, SE-75185 Uppsala; ${ }^{2}$ School of Biotechnology, \\ Division of Protein Technology, KTH - Royal Institute of Technology, SE-10691 Stockholm; ${ }^{3}$ Division of \\ Molecular Imaging, Department of Medicinal Chemistry, Uppsala University, SE-75183 Uppsala, Sweden
}

Received April 7, 2016; Accepted May 20, 2016

DOI: $10.3892 /$ ijo.2016.3614

\begin{abstract}
Targeted delivery of toxins is a promising way to treat disseminated cancer. The use of monoclonal antibodies as targeting moiety has provided proof-of-principle for this approach. However, extravasation and tissue penetration rates of antibody-based immunotoxins are limited due to antibody bulkiness. The use of a novel class of targeting probes, Affibody molecules, provides smaller toxin-conjugated constructs, which may improve targeting. Earlier, we have demonstrated that affitoxins containing a HER2targeting Affibody moiety and a deimmunized and truncated exotoxin A from Pseudomonas aeruginosa, PE38X8, provide highly selective toxicity to HER2-expressing cancer cells. To evaluate the influence of molecular design on targeting and biodistribution properties, a series of novel affitoxins were labelled with the residualizing radionuclide ${ }^{111} \mathrm{In}$. In this study, we have shown that the novel conjugates are more rapidly internalized compared with the parental affitoxin. The use of a $(\mathrm{HE})_{3}$ purification tag instead of a hexahistidine tag enabled significant $(\mathrm{p}<0.05)$ reduction of the hepatic uptake of the
\end{abstract}

Correspondence to: Professor Vladimir Tolmachev, Institute of Immunology, Genetic and Pathology, Uppsala University, Dag Hammarskjölds väg 20, SE-75185 Uppsala, Sweden

E-mail: vladimir.tolmachev@igp.uu.se

*Contributed equally

Abbreviations: ABD, albumin binding domain; mAbs, monoclonal antibodies; Fv, variable fragment; HER2, human epidermal growth factor receptor 2; HSA, human serum albumin; IMAC, immobilized metal-ion affinity chromatography; $\mathrm{K}_{\mathrm{D}}$, equilibrium dissociation constant; MSA, mouse serum albumin; PBS, phosphate-buffered saline; scFv, single-chain variable fragment; PE38, truncated exotoxin A from Pseudomonas aeruginosa

Key words: Affibody molecule, immunotoxin, albumin binding domain, PE38, HER2, biodistribution, ${ }^{111}$ In affitoxin in a murine model. Fusion of the affitoxin with an albumin-binding domain (ABD) caused appreciable extension of the residence time in circulation and several-fold reduction of the renal uptake. The best variant, ${ }^{111} \mathrm{In}-(\mathrm{HE})_{3}-\mathrm{Z}_{\mathrm{HER} 2}-\mathrm{ABD}-$ PE38X8, demonstrated receptor-specific accumulation in HER2-expressing SKOV-3 xenografts. In conclusion, a careful molecular design of scaffold protein based anticancer targeted toxins can appreciably improve their biodistribution and targeting properties.

\section{Introduction}

Chemotherapeutic treatment efficacy of disseminated cancer is limited by the indiscriminate toxicity of conventional agents. The use of monoclonal antibodies (mAbs), which selectively target cancer-specific antigens, increases treatment specificity in comparison with conventional chemotherapy. However, the clinical validation of therapeutic antibodies has revealed a modest efficacy of unconjugated mAbs $(1,2)$. A considerable number of patients were inherently resistant to unconjugated $\mathrm{mAbs}$ and the majority acquired resistance over time (3). The use of immunotoxins, which consist of a cytotoxic molecule coupled to an antibody or antibody fragment, selective for a cancer-specific antigen, is a possible approach to improve the efficacy of mAb therapy. The use of a potent cytotoxic drug and specific delivery of the drug conjugate to the tumour creates preconditions to improve the therapeutic outcome (4). The toxin PE38 (38 kDa), a truncated version of Pseudomonas aeruginosa exotoxin A, has been widely used in designing immunotoxins with high cytotoxic activity (5). After translocation to the cytosol, PE catalyses irreversible ribosylation of elongation factor 2 (EF-2). This consequently inhibits protein synthesis and leads to cell death. Derivatives of PE38 have been coupled to both immunoglobulin- (6) and non-immunoglobulin-based (7-10) targeting agents for treatment of several types of cancer. Such constructs showed an appreciable efficacy in preclinical models. However, PE38 was found to trigger immune responses, which limited repeated administration. Identification and removal of B- and T-cell recognition epitopes resulted in development of less immunogenic variants, such as PE38X8 (11-15). 
The successful use of targeted toxins is hampered by a number of physiological barriers (16). A precondition for effective treatment is delivery of the cytotoxic agent to as many cancer cells as possible, which is difficult with antibodies as targeting vectors due to their large size. The antibody variable fragments, $\mathrm{scFv}$ and $\mathrm{dsFv}$, have been extensively studied as promising targeting moieties for PE38-based immunotoxins in preclinical settings. Due to their smaller size compared to fulllength $\mathrm{mAbs}$, these molecules provided better penetration of solid tumours. Such constructs have successfully been applied for targeting HER2-overexpressing breast $(17,18)$, ovarian (19), prostate (20) and gastric (21) cancers. However, these small, toxin-conjugated domains had insufficient tumour localization due to their short plasma half-life (low bioavailability) in combination with a low maximum tolerated dose (MTD), which limited the amount of drug that could be injected $(22,23)$.

An alternative approach for the development of high affinity, small-size tumour targeting agents is the use of nonimmunoglobulin scaffold proteins. Affibody molecules are the first type of scaffold protein that has been applied for in vivo targeting. They are based on a 58 -amino acid $(6.5 \mathrm{kDa})$ scaffold derived from the B domain of staphylococcal protein A (24). By randomization of 13 surface amino acids, combinatorial libraries have been created. From these libraries, high-affinity Affibody variants binding with exquisite selectivity and subnanomolar affinity to desired molecular targets have been selected. These include HER2 (25), EGFR (26), IGF-1R (27), PDGFR $\beta$ (28), and HER3 (29). Affibody molecules have been successfully labelled with radionuclides including ${ }^{111} \mathrm{In},{ }^{99 \mathrm{~m}} \mathrm{Tc}$, ${ }^{68} \mathrm{Ga},{ }^{124} \mathrm{I}$, and ${ }^{18} \mathrm{~F}(26,29-32)$ or fluorophores $(33,34)$ for in vivo imaging. The $\beta$-emitting nuclides, ${ }^{177} \mathrm{Lu}$ and ${ }^{188} \operatorname{Re}(35-37)$, and toxins $(8,9)$ were conjugated to Affibody molecules for therapeutic applications. The radiolabelled anti-HER2 Affibody molecule $\mathrm{Z}_{\mathrm{HER} 2: 2891}$, showed specific tumour accumulation and high-contrast imaging in clinics $(38,39)$. Due to their small size, high affinity and relatively easy recombinant production in prokaryotes, Affibody molecules represent a promising alternative to immunoglobulin-based fragments for toxin delivery. The feasibility of using the anti-HER 2 Affibody molecule $\left(\mathrm{Z}_{\text {HER2:342 }}\right)$ genetically fused with the PE38-toxin has been demonstrated in vivo by Zielinski et al (9). However the affitoxin construct exhibited a short residence time in the bloodstream $\left(\mathrm{t}_{1 / 2}=8.69 \pm 1.31 \mathrm{~min}\right)$ due to rapid renal clearance. This made it necessary to inject the construct repeatedly in order to achieve therapeutically meaningful doses in murine models. Methods for prolongation of the in vivo half-life of Affibody-based targeting agents were developed earlier in our laboratories $(35,36)$. The Affibody molecule was fused with an albumin-binding domain (ABD) derived from the GA148-GA3 domain of streptococcal protein G (40), which resulted in binding to albumin in vivo and prevention of glomerular filtration. In addition, binding to albumin enables rescue by the FcRn-pathway from intracellular catabolism (41). The engineered $\mathrm{ABD}$ variant $\mathrm{ABD}_{035}$ binds with femtomolar affinity to human serum albumin as well as sub-nanomolar affinities to serum albumin from rat, mouse and cynomolgus monkey (42). Binding of the construct $Z_{\text {HER2:2891 }}-A D_{035}$ to serum albumin was clearly demonstrated in animals (36). The elimination half-life of the parental $Z_{\text {HER2:2891 }}$ Affibody molecule from blood was increased 80 -fold when conjugated to $\mathrm{ABD}_{035}$. In addition, the capacity of specific targeting of HER2-expressing xenografts was preserved in ABD-fused Affibody molecules (36).

The fusion toxin $\left(\mathrm{Z}_{\mathrm{HER} 2: 342}-\mathrm{PE} 38\right)$ reported by Zielinski et al (9), showed an elevated accumulation in the liver. That construct contained a Hexahistidine-tag to facilitate purification by immobilized metal ion affinity chromatography (IMAC). We have previously observed that the presence of an N-terminally placed hexahistidine-tag in $\mathrm{Z}_{\mathrm{HER} 2: 342}$ leads to elevated unspecific uptake in the liver. Incorporation of negatively charged glutamate residues into a histidine-containing-tag (resulting in a tag with the amino acid sequence HEHEHE or (HE) $)_{3}$ ) significantly reduced liver uptake, while still allowing efficient purification by IMAC (43). We have recently constructed and evaluated in vitro a novel tripartite fusion toxin $\left(\mathrm{Z}_{\mathrm{HER} 2: 2891} \mathrm{ABD}-\mathrm{PE} 38 \mathrm{X} 8\right)$, which includes the deimmunized PE38X8-toxin fused to the HER2-binding Affibody molecule HEHEHE- $Z_{\text {HER2:2891 }}$ and the half-life extending albumin binding domain $\mathrm{ABD}_{035}(10)$. The fusion toxin was successfully produced in E. coli and all three components of the construct preserved their functionality. Despite the lower affinity of $Z_{\text {HER2:2891 }}$-ABD-PE38X8 compared to the parental $Z_{\mathrm{HER} 2: 2891}$ molecule, the cytotoxic potency of the fusion toxin was 1000 -fold higher compared to a non-specific control.

In this study, we have evaluated the influence of modifications in the molecular design of affitoxins on cellular processing and biodistribution properties. For this purpose, several affitoxin-variants were labelled with the residualizing radionuclide ${ }^{111}$ In. The internalization by living HER2-expressing cells was measured, the influence of the composition of the histidinecontaining tag on biodistribution was evaluated, and the effect of fusion to ABD on blood clearance rate was investigated. The tumour targeting properties of the most promising variant, $\mathrm{Z}_{\mathrm{HER} 2: 2891}-\mathrm{ABD}-\mathrm{PE} 38 \mathrm{X} 8$, were assessed.

\section{Materials and methods}

General. Affibody-based toxins $\mathrm{H}_{6}-\mathrm{Z}_{\mathrm{HER} 2}-\mathrm{PE} 38,(\mathrm{HE})_{3}-\mathrm{Z}_{\mathrm{HER} 2}-$ PE38X8, (HE) ${ }_{3}-Z_{\mathrm{HER} 2}-\mathrm{ABD}-\mathrm{PE} 38 \mathrm{X} 8$ and (HE) ${ }_{3}-\mathrm{Z}_{\mathrm{taq}}-\mathrm{ABD}-$ PE38X8 were produced and analyzed as described earlier (10). HER2-expressing SKOV-3 cells (ATCC) were used in all experiments. For in vitro experiments $7 \times 10^{5} \mathrm{SKOV}-3$ cells per dish were seeded the day before the experiment. An unpaired $t$-test was used to determine significant difference $(p<0.05)$ between measured values.

Conjugation and labelling. For labelling with ${ }^{111}$ In, affitoxins were conjugated with a benzylisothiocyanate derivative of the CHX-A"-DTPA chelator (Macrocyclics, Dallas, TX, USA) as described earlier (44). For this purpose, the protein (630-1,100 $\mu \mathrm{g}$ in $490 \mu 10.07 \mathrm{M}$ sodium borate, $\mathrm{pH}$ 9.3) was mixed with 1.1-fold molar excess of CHX-A"-DTPA $(1 \mathrm{mg} / \mathrm{ml}$ in the same buffer). The mixture was vortexed and then incubated overnight at ambient temperature. For removal of unreacted chelator and buffer exchange, the mixture was passed through a NAP-5 column (GE Healthcare, Uppsala, Sweden), equilibrated and eluted with $0.2 \mathrm{M}$ ammonium acetate, $\mathrm{pH}$ 5.5. The high molecular weight fraction was collected according to the manufacturer's instructions. The conjugate was stored at 
$-20^{\circ} \mathrm{C}$. This methodology provides conjugation of an average of one chelator per Affibody molecule.

Labelling was performed by mixing the conjugate $(200 \mu \mathrm{g}$ in $200 \mu \mathrm{l} 0.2 \mathrm{M}$ ammonium acetate, $\mathrm{pH} 5.5)$ with ${ }^{111}$ In chloride (15 MBq in $40 \mu \mathrm{l} 0.05 \mathrm{M} \mathrm{HCl}$ ). After 60-min incubation at r.t., the radiolabelled conjugate was purified using a NAP-5 column pre-equilibrated and eluted with PBS. Radiochemical yield and purity of the conjugates were determined using silicaimpregnated ITLC strips (150-771 Dark Green Tec-Control Chromatography strips, Biodex Medical Systems) eluted with $0.2 \mathrm{M}$ citric acid. The relative radioactivity associated with the affitoxins $\left(\mathrm{R}_{\mathrm{f}}=0.0\right)$ and free ${ }^{111} \mathrm{In}\left(\mathrm{R}_{\mathrm{f}}=1.0\right)$ was measured using the Cyclone Storage Phosphor System (Perkin-Elmer).

Cellular binding and processing by HER2-expressing cells in vitro. An in vitro specificity test was performed according to the method described earlier (45). Briefly, a solution of radiolabelled affitoxin $(10 \mathrm{nM})$ was added to the cell plates. For blocking, $1 \mu \mathrm{M}$ of non-labelled anti-HER2 Affibody molecule $\left(\mathrm{H}_{6}-\mathrm{Z}_{\mathrm{HER} 2: 342}\right)$ was added $15 \mathrm{~min}$ before the radiolabelled conjugates to saturate the receptors in some of dishes. The cells were incubated during $1 \mathrm{~h}$ at $37^{\circ} \mathrm{C}$. Thereafter, the medium was collected, the cells were detached by a trypsinEDTA solution and cell-bound radioactivity was measured using an automated $\gamma$-spectrometer (1480 Wizard; Wallac Oy). The experiment was performed in triplicates.

To assess the rate of internalization of the radiolabelled affitoxins by SKOV-3 cells, a modified acid wash method was used (45). Briefly, the cells were incubated with the radiolabelled affitoxins $(10 \mathrm{nM})$ at $37^{\circ} \mathrm{C}$. At $1,2,4$ and $6 \mathrm{~h}$ after incubation start, the medium was removed. To collect membrane-bound radioactivity, the cells were treated with $0.2 \mathrm{M}$ glycine buffer containing $4 \mathrm{M}$ urea, $\mathrm{pH} 2.5$, for $5 \mathrm{~min}$ on ice. To collect radioactivity internalized by the cells, treatment with $1 \mathrm{M} \mathrm{NaOH}$ at $37^{\circ} \mathrm{C}$ for $0.5 \mathrm{~h}$ was performed. The radioactivity of the collected fractions was measured. The experiment was performed in triplicates.

The affinity between radiolabelled affitoxins and living HER 2 expressing SKOV-3 cells was measured using a LigandTracer Yellow instrument (Ridgeview Instruments, Vänge, Sweden) as described earlier (46). To measure the kinetics during association, three different concentrations $(0.7$, 2 and $6 \mathrm{nM})$ of the affitoxins, ${ }^{111} \mathrm{In}-(\mathrm{HE})_{3}-\mathrm{Z}_{\mathrm{HER} 2}-\mathrm{P} 38 \mathrm{X} 8$ and ${ }^{111} \mathrm{In}-(\mathrm{HE})_{3}-\mathrm{Z}_{\mathrm{HER} 2}-\mathrm{ABD}-\mathrm{P} 38 \mathrm{X} 8$, were used.

Animal studies. The animal experiments were planned and performed in accordance with national legislation on protection of laboratory animals. The animal studies were approved by the Local Ethics Committee for Animal Research in Uppsala.

The influence of the composition of the histidine-containing tag on hepatic uptake. To evaluate the influence of the composition of the histidine-containing tag, one group of four mice was injected with $2.4 \mu \mathrm{g}(51 \mathrm{pmol})$ of the hexahistidine-tag containing affitoxin, ${ }^{111} \mathrm{In}-\mathrm{H}_{6}-\mathrm{Z}_{\mathrm{HER} 2}$-PE38 (20 kBq in $100 \mu \mathrm{l}$ PBS per mouse). Another group of mice was injected with $2.4 \mu \mathrm{g}(51 \mathrm{pmol})$ of ${ }^{111} \mathrm{In}-(\mathrm{HE})_{3}-\mathrm{Z}_{\mathrm{HER} 2}$-PE38X8 containing the HEHEHE-tag (20 kBq in $100 \mu \mathrm{l}$ PBS per mouse). The mice were sacrificed $4 \mathrm{~h}$ after injection by an overdose of anaesthesia solution (30 $\mu \mathrm{l}$ of solution per gram body weight; Ketalar: $10 \mathrm{mg} / \mathrm{ml}$; Rompun: $1 \mathrm{mg} / \mathrm{ml})$. Blood was withdrawn by heart puncture. Blood, heart, lung, salivary gland, liver, spleen, pancreas, stomach, kidney, colon, skin, muscle, bone, gastrointestinal tract (with its content) and remaining carcass were collected and weighed. The radioactivity of the organs and standards of injected solutions was measured using an automated gamma-spectrometer (1480 Wizard; Wallac Oy). Tissue uptake values were calculated as percent of injected dose per gram tissue weight $(\% \mathrm{ID} / \mathrm{g})$ except for the gastrointestinal tract (with its content) and remaining carcass, which was calculated as \%ID per whole tissue sample.

The influence of ABD-fusion on biodistribution. To compare the biodistribution of ${ }^{111} \mathrm{In}-(\mathrm{HE})_{3}-\mathrm{Z}_{\mathrm{HER} 2}-\mathrm{ABD}-\mathrm{P} 38 \mathrm{X} 8$ and ${ }^{111} \mathrm{In}-(\mathrm{HE})_{3}-\mathrm{Z}_{\mathrm{HER} 2}-\mathrm{P} 38 \mathrm{X} 8$, thirty-two female NMRI mice $(27.3 \pm 2 \mathrm{~g})$ were randomised to eight groups with four mice each. Four groups were intravenously injected with $2.4 \mu \mathrm{g}$ $(51 \mathrm{pmol})$ of ${ }^{111} \mathrm{In}-(\mathrm{HE})_{3}-\mathrm{Z}_{\mathrm{HER} 2}-\mathrm{P} 38 \mathrm{X} 8$, and four groups with $2.4 \mu \mathrm{g}(48 \mathrm{pmol}){ }^{111} \mathrm{In}-(\mathrm{HE})_{3}-\mathrm{Z}_{\mathrm{HER} 2}-\mathrm{ABD}-\mathrm{P} 38 \mathrm{X} 8$. The injected radioactivity was $20 \mathrm{kBq}$ per mouse. At 1, 4, 24 and $48 \mathrm{~h}$ after injection, the distribution of each conjugate was measured in one group of mice, as described above.

Biodistribution of ${ }^{111}$ In- $(\mathrm{HE})_{3}-Z_{\mathrm{HER}_{2}}-\mathrm{ABD}-\mathrm{P} 38 \mathrm{X} 8$ in tumour bearing mice. For tumour implantation, female Balb/c nu/nu mice (Charles River Laboratories) were subcutaneously injected with $8 \times 10^{6}$ SKOV-3 cells on the right hind leg. At the time of experiment the average tumour weight was $0.52 \pm 0.15 \mathrm{~g}$ and the average animal weight was $18.6 \pm 0.98 \mathrm{~g}$.

The mice were randomized into four groups $(n=4)$. Three groups were intravenously injected with $2 \mu \mathrm{g}(40 \mathrm{pmol})$ HER2-specific ${ }^{111} \mathrm{In}-(\mathrm{HE})_{3}-\mathrm{Z}_{\mathrm{HER} 2}$-ABD-P38X8 $(20 \mathrm{kBq}$ in $100 \mu 1$ of PBS per mouse). Mice were euthanized at 1, 4 and $24 \mathrm{~h}$ after injection, and the biodistribution was measured as described above. To confirm that the tumour accumulation of ${ }^{111} \mathrm{In}-\mathrm{Z}_{\mathrm{HER} 2}$-ABD-PE38X8 is HER2-specific, an additional group of mice was injected with $2 \mu \mathrm{g}(40 \mathrm{pmol}){ }^{111} \mathrm{In}-(\mathrm{HE})_{3^{-}}$ $\mathrm{Z}_{\mathrm{taq}}$-ABD-PE38X8 (20 kBq in $100 \mu \mathrm{l}$ of PBS per mouse). The mice were euthanized at $24 \mathrm{~h}$ after injection and the biodistribution was measured.

Toxicity of $(\mathrm{HE})_{3}-Z_{\mathrm{HER}_{2}}-A B D-P 38 X 8$. Eighteen female Balb/c mice (Taconic $M \& B$ ) were randomized into three groups $(n=6)$. The average animal weight was $21.4 \pm 0.5 \mathrm{~g}$. The mice received five intravenous injections of (HE) $)_{3}-\mathrm{Z}_{\mathrm{HER} 2}-\mathrm{ABD}$ P38X8 $(0.137,0.275$ or $0.55 \mathrm{mg} / \mathrm{kg}$, every fourth day). The mice were followed for 9 days after the last injection (total of 25 days after the start of the experiment) to observe any dose-dependent signs of morbidity or mortality. The response to treatment was assessed according to the Guidelines for Pain and Distress in Laboratory Animals from the National Institute of Cancer (NIH, USA) adopted by Uppsala University. Assessment parameters included exterior, general conditions, behaviour, stress, pain, ataxia, appetite, sores and blistering, eye's inflammation, porphyria, function of urinary and gastrointestinal systems, respiration and body weight. After the mice were sacrificed the heart, liver and kidneys were collected, fixated and further investigated. 


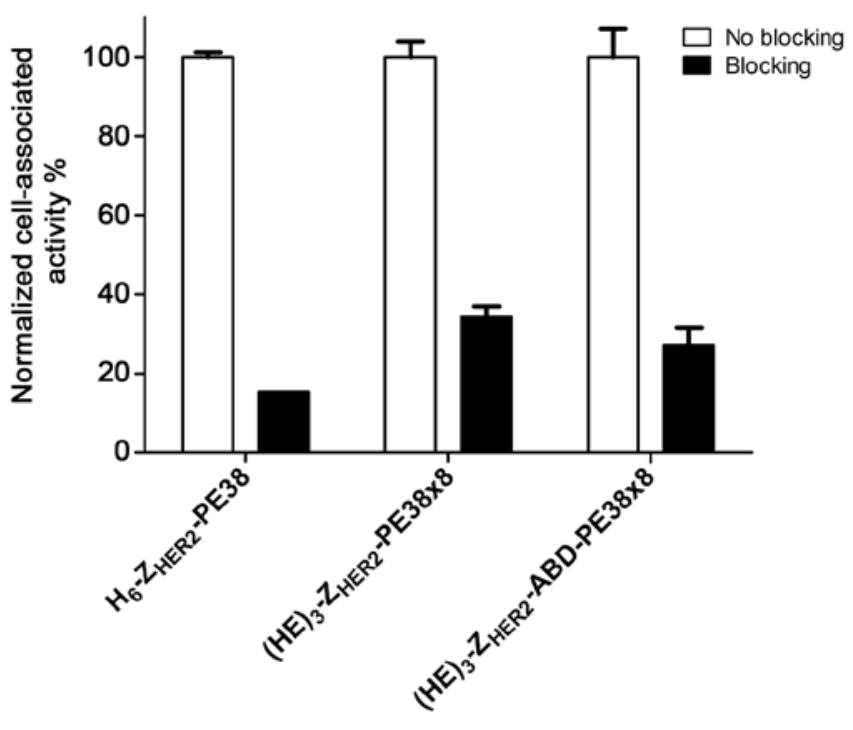

Figure 1. Specificity of binding of ${ }^{111}$ In-labelled affitoxins to HER2-expressing SKOV-3 ovarian cancer cells in vitro. For pre-saturation of HER2 on the cells (blocked), a 100-fold molar excess of unlabelled Affibody molecule was added prior to the ${ }^{111}$ In labeled affitoxins. The experiment was performed in triplicates. Error bars correspond to \pm SD.

\section{Results}

Production and initial characterization. Essentially pure affitoxins (purity $>95 \%$ ) could be obtained after expression in Escherichia coli followed by purification by IMAC, anion exchange chromatography and gel filtration. The molecular mass of each construct was verified by mass spectrometry. The equilibrium dissociation constant between the affitoxins and HER2 was measured by a biosensor and was found to be between 2 and $5 \mathrm{nM}$ for $\mathrm{Z}_{\mathrm{HER} 2}$-containing constructs following a 1:1 binding model. The $\mathrm{Z}_{\mathrm{taq}}$-containing construct has no measurable affinity to HER2.

Conjugation and labelling. The labelling yield was $>99 \%$ for ${ }^{111} \mathrm{In}-\mathrm{H}_{6}-\mathrm{Z}_{\mathrm{HER} 2}-\mathrm{PE} 38$ and ${ }^{111} \mathrm{In}-(\mathrm{HE})_{3}-\mathrm{Z}_{\mathrm{HER} 2}-\mathrm{PE} 38 \mathrm{X} 8$. For ${ }^{111} \mathrm{In}-(\mathrm{HE})_{3}-\mathrm{Z}_{\mathrm{HER} 2}-\mathrm{ABD}-\mathrm{P} 38 \mathrm{X} 8$, the yield was in the range of 84-95\%. Purification using NAP-5 size-exclusion columns provided a radiochemical purity of $>99 \%$ for all labelled affitoxins. The labelling yield of the control Affibody $(\mathrm{HE})_{3}$ $\mathrm{Z}_{\mathrm{taq}}$-ABD-PE38X8 was $90.5 \%$ and its radiochemical purity was $99.9 \%$.

Cellular binding and processing by HER2-expressing cells in vitro. Binding of ${ }^{111}$ In-labelled $\mathrm{H}_{6}-\mathrm{Z}_{\mathrm{HER} 2}-\mathrm{PE} 38,(\mathrm{HE})_{3}-\mathrm{Z}_{\mathrm{HER} 2^{-}}$ PE38X8, and (HE) $)_{3}-Z_{\mathrm{HER} 2}-\mathrm{ABD}-\mathrm{PE} 38 \mathrm{X} 8$ to SKOV-3 cells was HER2 specific. The cell associated radioactivity was significantly reduced when the receptors were pre-saturated with a large excess of non-labelled anti-HER2 Affibody molecule $\left(\mathrm{H}_{6}-\mathrm{Z}_{\text {HER } 2: 342}\right)$ (Fig. 1).

All conjugates demonstrated rapid binding to HER2expressing cells and cell associated radioactivity reached a plateau after 1-2 h of incubation (Fig. 2). Cell counting demonstrated that $6 \mathrm{~h}$ after incubation with a $10 \mathrm{nM}$ solution of conjugate, the amount of cells per dish decreased marginally. The internalisation pattern of ${ }^{111} \mathrm{In}-\mathrm{H}_{6}-\mathrm{Z}_{\mathrm{HER} 2}-\mathrm{PE} 38$ differed from that of ${ }^{111} \mathrm{In}-(\mathrm{HE})_{3}-\mathrm{Z}_{\mathrm{HER} 2}-\mathrm{PE} 38 \mathrm{X} 8$ and ${ }^{111} \mathrm{In}-(\mathrm{HE})_{3}$ $\mathrm{Z}_{\mathrm{HER} 2}-\mathrm{ABD}-\mathrm{P} 38 \mathrm{X} 8$. The ${ }^{111} \mathrm{In}-\mathrm{H}_{6}-\mathrm{Z}_{\mathrm{HER} 2}-\mathrm{PE} 38$ affitoxin had an internalisation pattern similar to its parental molecule ${ }^{111}$ In-DOTA-Z $Z_{\text {HER2:342 }}$ (45), characterised by slow internalisation. After $6 \mathrm{~h}$ of continuous incubation, $<30 \%$ of cell associated radioactivity was internalised, but neither cell uptake nor the internalised fraction increased after $2 \mathrm{~h}$ of incubation. The internalisation pattern of ${ }^{111} \mathrm{In}-(\mathrm{HE})_{3}-\mathrm{Z}_{\mathrm{HER} 2}-\mathrm{PE} 38 \mathrm{X} 8$ and ${ }^{111} \mathrm{In}-(\mathrm{HE})_{3}-\mathrm{Z}_{\mathrm{HER} 2}-\mathrm{ABD}-\mathrm{P} 38 \mathrm{X} 8$ demonstrated very rapid internalisation and after $2 \mathrm{~h}$ of continuous incubation, $65-70 \%$ cell
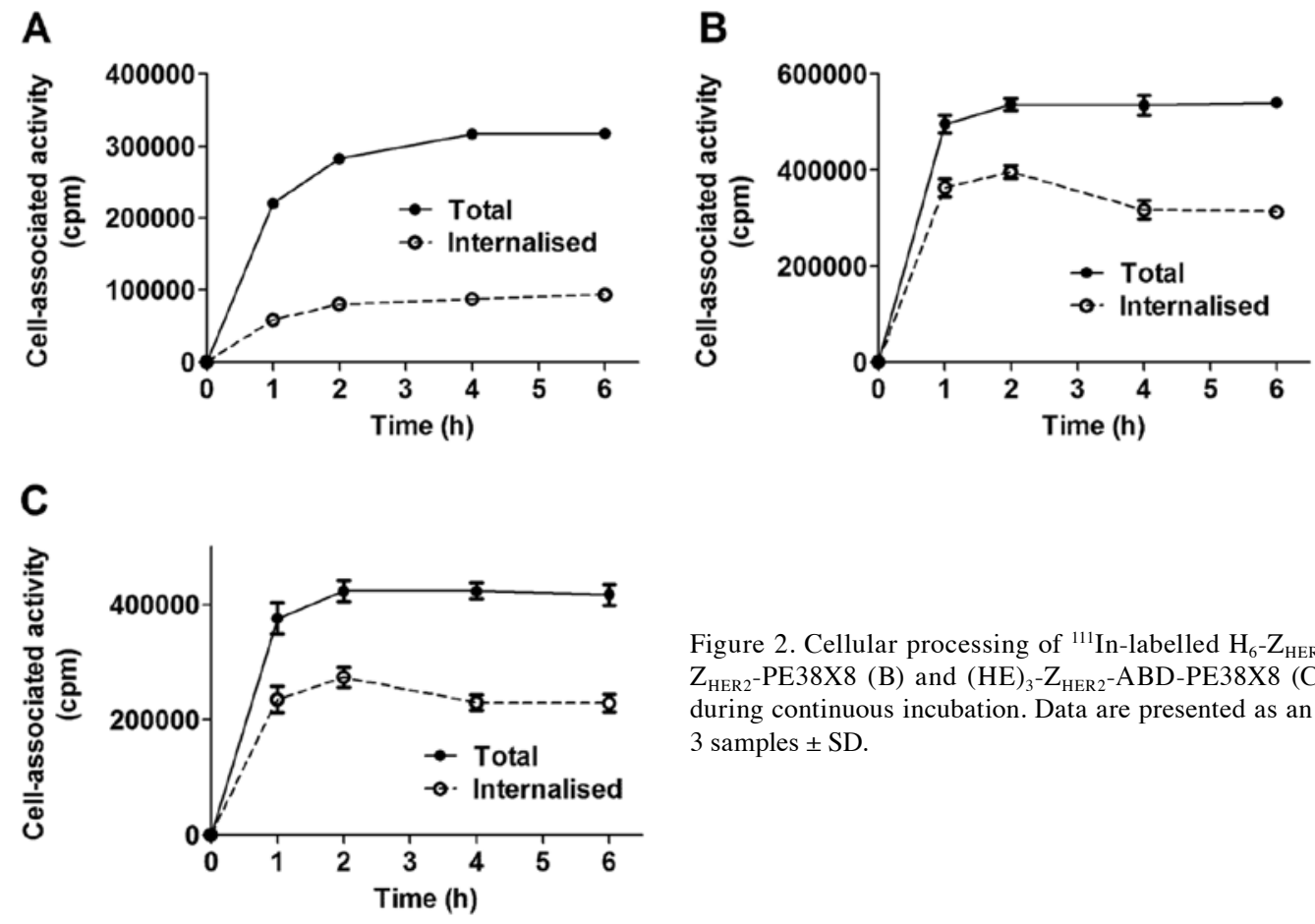

Figure 2. Cellular processing of ${ }^{111}$ In-labelled $\mathrm{H}_{6}-\mathrm{Z}_{\mathrm{HER} 2}-\mathrm{PE} 38$ (A), (HE) ${ }_{3}$ $\mathrm{Z}_{\mathrm{HER} 2}-\mathrm{PE} 38 \mathrm{X} 8$ (B) and (HE) ${ }_{3}-\mathrm{Z}_{\mathrm{HER} 2}-\mathrm{ABD}-\mathrm{PE} 38 \mathrm{X} 8$ (C) by SKOV-3 cells during continuous incubation. Data are presented as an average value from 3 samples \pm SD. 
A

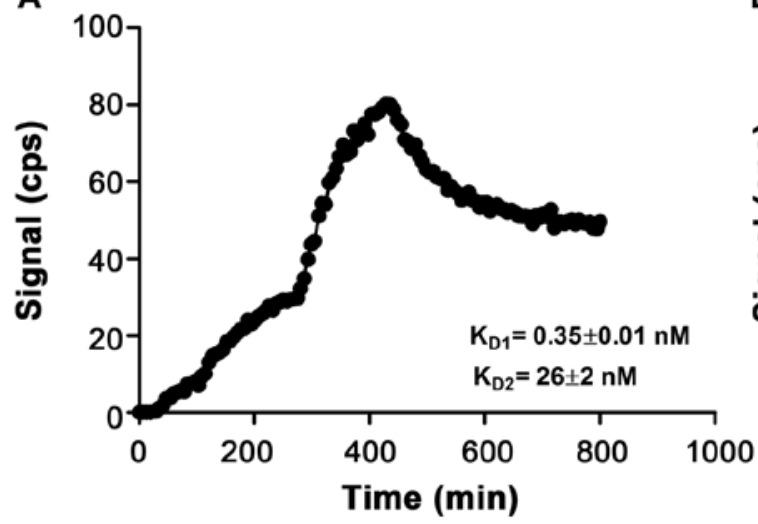

B

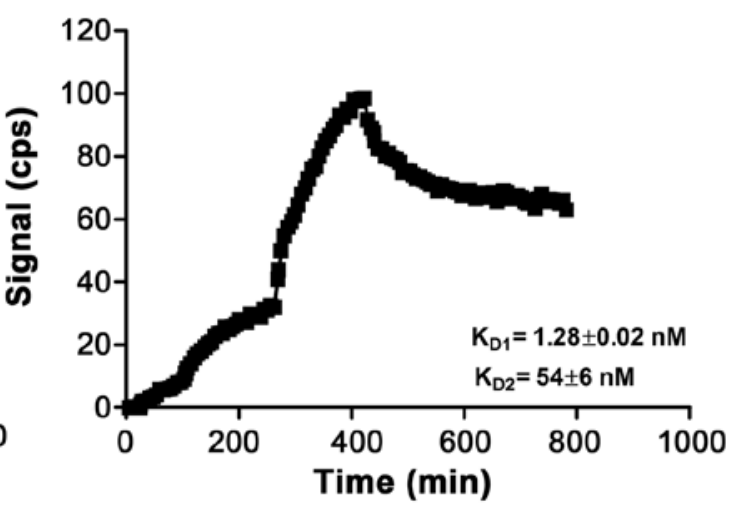

Figure 3. Representative LigandTracer sensorgrams (binding of ${ }^{111} \mathrm{In}-(\mathrm{HE})_{3}-\mathrm{Z}_{\mathrm{HER} 2}-\mathrm{ABD}-\mathrm{PE} 38 \mathrm{x} 8$ (A) and ${ }^{111} \mathrm{In}-(\mathrm{HE})_{3}-\mathrm{Z}_{\mathrm{HER} 2}-\mathrm{PE} 38 \mathrm{x} 8$ (B) to SKOV-3 cells).

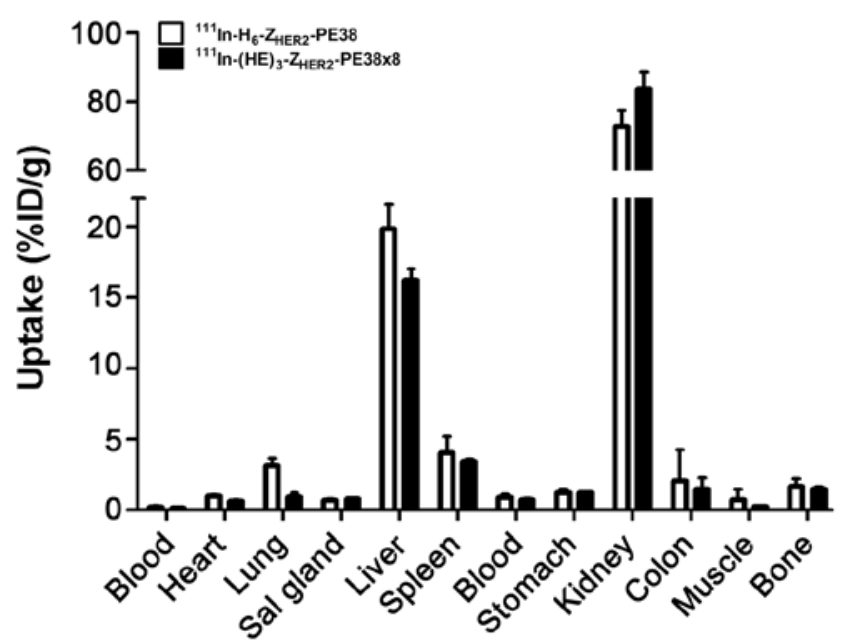

Figure 4. Comparative biodistribution of ${ }^{111} \mathrm{In}-\mathrm{H}_{6}-\mathrm{Z}_{\mathrm{HER}}-\mathrm{PE} 38$ and ${ }^{111} \mathrm{In}-(\mathrm{HE})_{3^{-}}$ $\mathrm{Z}_{\mathrm{HER} 2}-\mathrm{PE} 38 \mathrm{x} 8 \mathrm{in}$ female NMRI mice, $4 \mathrm{~h}$ after injection. The uptake values are presented as an average value from 4 animals \pm SD.

associated radioactivity was internalised. Further incubation led to slight decrease of the internalised fraction.

The results from the real-time radiotracer-receptor interaction measurement, using a LigandTracer, are shown in Fig. 3. The association and dissociation phases of ${ }^{111} \mathrm{In}$-labeled $(\mathrm{HE})_{3^{-}}$$\mathrm{Z}_{\mathrm{HER} 2}-\mathrm{ABD}-\mathrm{P} 38 \mathrm{X} 8$ and $(\mathrm{HE})_{3}-\mathrm{Z}_{\mathrm{HER} 2}-\mathrm{P} 38 \mathrm{X} 8$ with SKOV-3 cells were best fitted to a 1:2 interaction model, suggesting that each conjugate has two dissociation constants: $\mathrm{K}_{\mathrm{D} 1}=0.35 \pm 0.01 \mathrm{nM}$ and $\mathrm{K}_{\mathrm{D} 2}=26 \pm 2 \mathrm{nM}$ for ${ }^{111} \mathrm{In}-(\mathrm{HE})_{3}-\mathrm{Z}_{\mathrm{HER} 2}-\mathrm{ABD}-\mathrm{P} 38 \mathrm{X} 8$, and $\mathrm{K}_{\mathrm{D} 1}=1.28 \pm 0.02 \mathrm{nM}$ and $\mathrm{K}_{\mathrm{D} 2}=54 \pm 6 \mathrm{nM}$ for ${ }^{111} \mathrm{In}-(\mathrm{HE})_{3}-\mathrm{Z}_{\mathrm{HER}^{-}}$ P38X8.

The influence of the composition of the histidine-tag on hepatic uptake. Data concerning the influence of the composition of the purification tag on biodistribution of the anti-HER2 Affibody fused-toxins are presented in Fig. 4. The HEHEHE-containing variant ${ }^{111} \mathrm{In}-(\mathrm{HE})_{3}-\mathrm{Z}_{\mathrm{HER} 2}-\mathrm{PE} 38 \mathrm{X} 8$ demonstrated significantly $(\mathrm{p}<0.05)$ lower uptake in the liver compared to ${ }^{111} \mathrm{In}-\mathrm{H}_{6}-\mathrm{Z}_{\mathrm{HER} 2}-\mathrm{PE} 38(16.2 \pm 0.8$ vs $20 \pm 2 \% \mathrm{ID} / \mathrm{g})$. It has to be noted, that the hepatic uptake remained high even for ${ }^{111} \mathrm{In}-(\mathrm{HE})_{3}-\mathrm{Z}_{\mathrm{HER} 2}-\mathrm{PE} 38 \mathrm{X} 8$. The radioactivity concentration

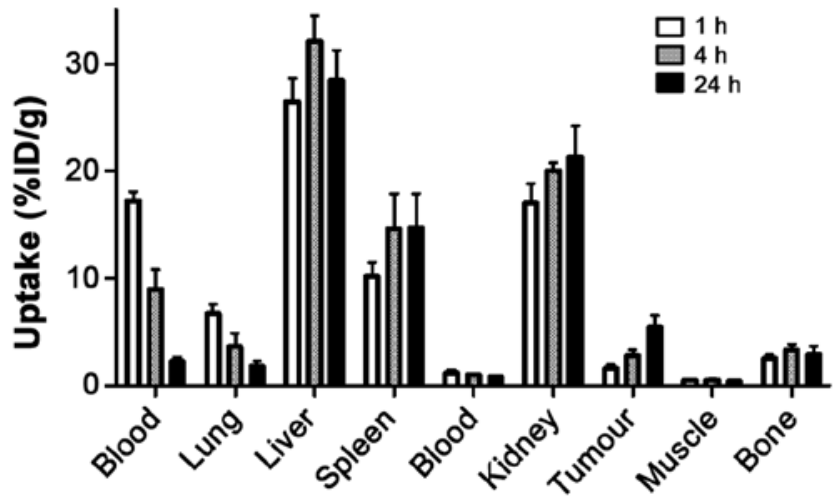

Figure 5. Biodistribution of ${ }^{111}$ In-ZHER2-ABD-PE38x8 in female Balb/c nu/nu mice bearing HER2-expressing SKOV-3 xenografts. Data are presented as an average value from 4 animals \pm SD.

of ${ }^{111} \mathrm{In}-(\mathrm{HE})_{3}-\mathrm{Z}_{\mathrm{HER} 2}-\mathrm{PE} 38 \mathrm{X} 8$ was also significantly $(\mathrm{p}<0.05)$ lower in blood, heart and lung. The renal uptake was significantly higher for ${ }^{111} \mathrm{In}-(\mathrm{HE})_{3}-\mathrm{Z}_{\mathrm{HER} 2}-\mathrm{PE} 38 \mathrm{X} 8(84 \pm 5 \% \mathrm{ID} / \mathrm{g})$ compared to ${ }^{111} \mathrm{In}-\mathrm{H}_{6}-\mathrm{Z}_{\mathrm{HER} 2}-\mathrm{PE} 38(73 \pm 5 \% \mathrm{ID} / \mathrm{g})$.

Influence of $A B D$-fusion on biodistribution. The comparison of biodistribution of ${ }^{111} \mathrm{In}-(\mathrm{HE})_{3}-\mathrm{Z}_{\mathrm{HER} 2}-\mathrm{ABD}-\mathrm{PE} 38 \mathrm{X} 8$ and ${ }^{111} \mathrm{In}-(\mathrm{HE})_{3}-\mathrm{Z}_{\mathrm{HER} 2}-\mathrm{PE} 38 \mathrm{X} 8$ in female NMRI mice is summarized in Table I. The data showed prominently higher concentration of ${ }^{111} \mathrm{In}-(\mathrm{HE})_{3}-\mathrm{Z}_{\mathrm{HER} 2} \mathrm{ABD}-\mathrm{PE} 38 \mathrm{X} 8$ in the blood compared to the non-ABD fused ${ }^{111} \mathrm{In}-(\mathrm{HE})_{3}-\mathrm{Z}_{\mathrm{HER} 2}-\mathrm{PE} 38 \mathrm{X} 8$ variant, at all time-points. This resulted in overall 2-foldhigher body retention of ${ }^{111} \mathrm{In}-(\mathrm{HE})_{3}-\mathrm{Z}_{\mathrm{HER} 2}-\mathrm{ABD}-\mathrm{PE} 38 \mathrm{X} 8$. The data also demonstrated a 5 -fold-lower radioactivity uptake in the kidneys for ${ }^{111} \mathrm{In}-(\mathrm{HE})_{3}-\mathrm{Z}_{\mathrm{HER} 2}-\mathrm{ABD}-\mathrm{PE} 38 \mathrm{X} 8$. There was similar uptake of both conjugates in the liver and gastrointestinal tract at all time-points. The longer residence time in blood of ${ }^{111} \mathrm{In}-(\mathrm{HE})_{3}-\mathrm{Z}_{\mathrm{HER} 2}$-ABD-PE38X8 was not directly translated to elevated uptake in the studied organs.

Biodistribution of ${ }^{111}$ In- $(H E)_{3}-Z_{H E R 2}-A B D-P E 38 X 8$ in tumour bearing mice. Data concerning the biodistribution of ${ }^{111} \mathrm{In}-(\mathrm{HE})_{3}-\mathrm{Z}_{\mathrm{HER} 2}$-ABD-PE38X8 in mice bearing SKOV-3 xenografts are presented in Fig. 5. The data were in good 


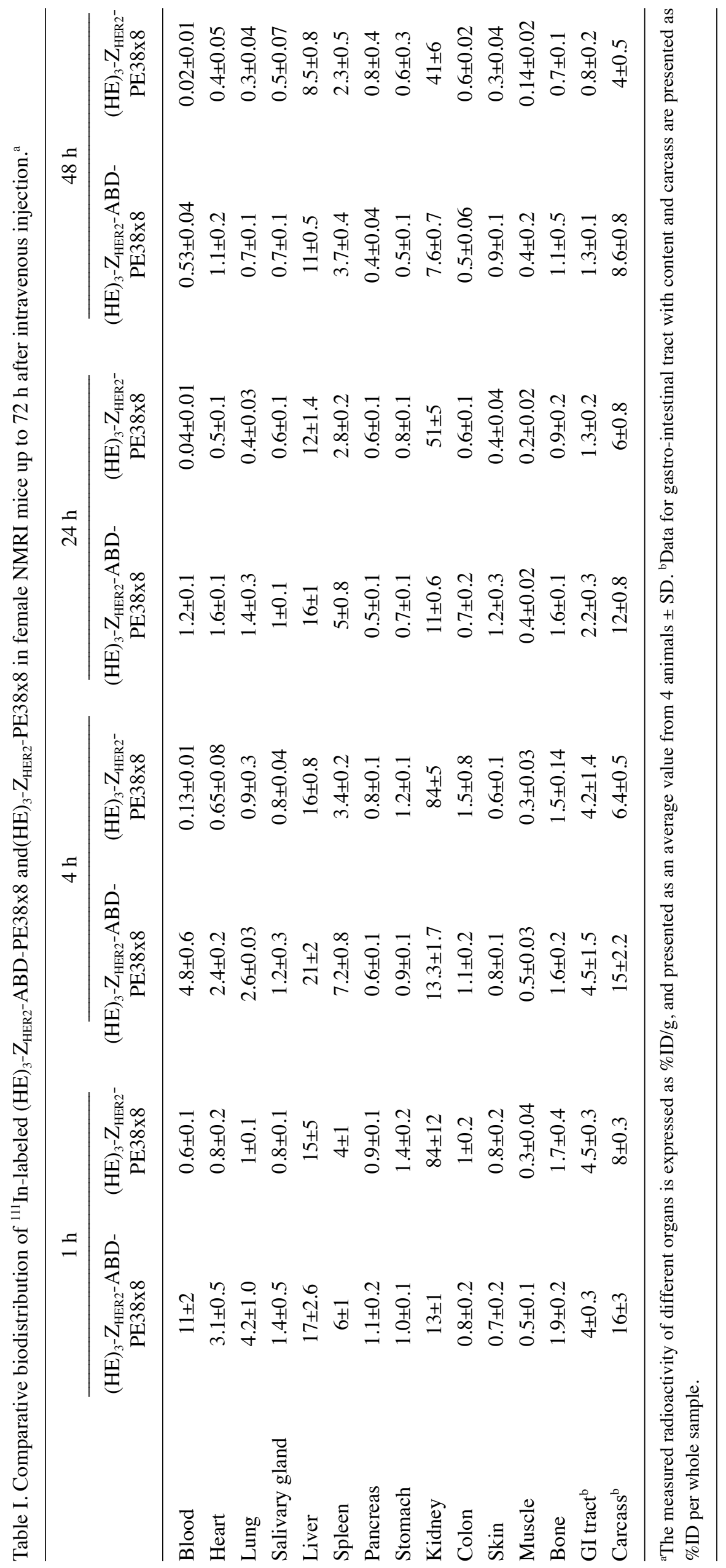




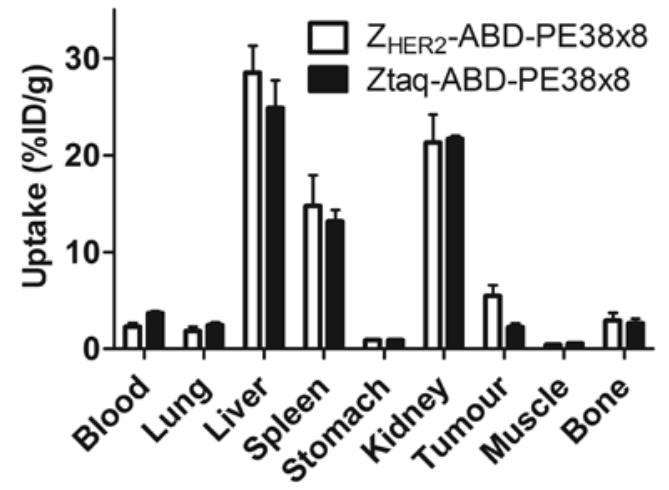

Figure 6. Comparative biodistribution of ${ }^{111} \mathrm{In}$-labelled $\mathrm{Z}_{\mathrm{HER} 2}-\mathrm{ABD}-\mathrm{PE} 38 \mathrm{x} 8$ and $Z_{\text {taq }}$-ABD-PE38x8 in female Balb/c nu/nu mice bearing HER2 expressing SKOV-3 xenografts. Data are presented as an average value from 4 animals $\pm \mathrm{SD}$.

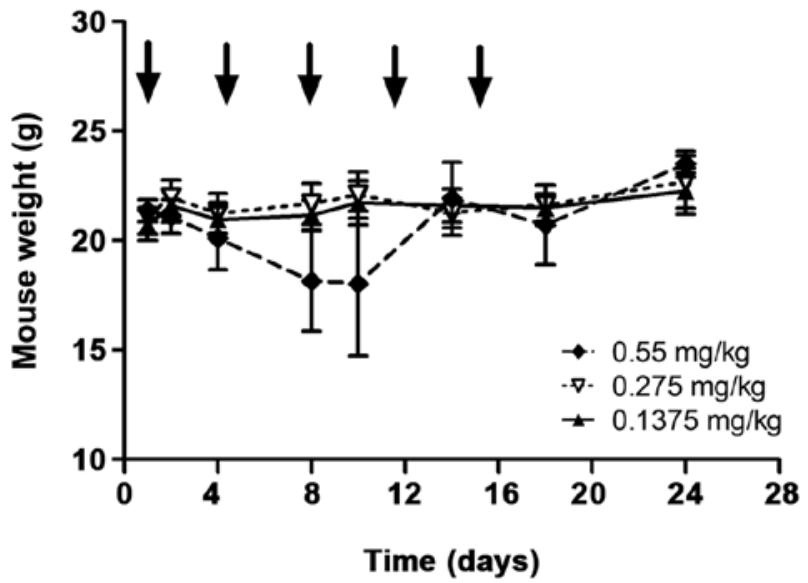

Figure 7. Change in weight over time in female Balb/c mice injected with different doses of $(\mathrm{HE})_{3}-\mathrm{Z}_{\mathrm{HER} 2}-\mathrm{ABD}-\mathrm{P} 38 \times 8$ as indicated by arrows. Data are presented as an average value from 6 animals \pm SD.

agreement with the biodistribution data in healthy NMRI mice except for elevated uptake in blood, liver, spleen and the kidneys, which can be explained by a difference in weight and volume. The tumour accumulation of ${ }^{111} \mathrm{In}-(\mathrm{HE})_{3}-\mathrm{Z}_{\mathrm{HER} 2}-\mathrm{ABD}-$ $\mathrm{PE} 38 \mathrm{X} 8$ was $1.6 \pm 0.4 \% \mathrm{ID} / \mathrm{g}$ at $1 \mathrm{~h}$ after injection and continued to increase with time up to $5.5 \pm 1 \% \mathrm{ID} / \mathrm{g}$ at $24 \mathrm{~h}$ after injection. By $24 \mathrm{~h}$ after injection, the uptake in the tumour was higher than the uptake in any other studied organ except for the liver, spleen and the kidneys. The results of the targeting specificity test are presented in Fig. 6 . The radioactivity concentration in the tumour was 2.7 -fold higher for ${ }^{111} \mathrm{In}-(\mathrm{HE})_{3}-\mathrm{Z}_{\mathrm{HER} 2}-\mathrm{ABD}-\mathrm{PE} 38 \mathrm{X} 8$ than for the control fusion toxin ${ }^{111} \mathrm{In}-(\mathrm{HE})_{3}-\mathrm{Z}_{\mathrm{taq}}-\mathrm{ABD}-\mathrm{PE} 38 \mathrm{X} 8$, which does not bind to HER2 $(p<0.05)$. There was no significant difference in the radioactivity concentrations in any other organs and tissue samples.

Toxicity of $(\mathrm{HE})_{3}-Z_{\mathrm{HER} 2}-A B D-P E 38 X 8$. No morbidity (change in weight, appearance or behaviour) or mortality was observed in the groups injected with 0.137 and $0.275 \mathrm{mg} / \mathrm{kg}$ (HE) $)_{3}-Z_{\text {HER2 }}$-ABD-PE38X8. One mouse in the group injected with $0.55 \mathrm{mg} / \mathrm{kg}$ affitoxin had a critical weight loss and was euthanized after the third injection. Other mice in this group started to lose weight after the second injection (day 8) but recovered by day 14 (Fig. 7). However tissue viability analysis of the heart, liver and kidneys from this group did not show any morphological differences or signs of injury compared to tissues from the other two groups (data not shown).

\section{Discussion}

The successful therapeutic implementation of Affibodybased toxin is hampered by their short residence time in the circulation and uptake in normal tissues, particularly the liver (9). Previous data suggest that small changes in the physiochemical properties of Affibody-based targeting agents may influence tumour targeting properties and overall biodistribution considerably (47). In this study, an adequate toxin delivery was achieved by modification in the molecular design of the affitoxin molecule. This involved the use of the deimmunized toxin PE38X8, prolongation of the plasma half-life by conjugation to ABD and minimization of the uptake in normal tissues (particularly liver) using the HEHEHE-tag.

Zielinski and co-workers, developed and studied a recombinant protein combining a HER2-specific Affibody and the PE38 toxin $\left(\mathrm{H}_{6}-\mathrm{Z}_{\mathrm{HER} 2}-\mathrm{PE} 38\right)$ (9). Their HER2-Affitoxin was labelled with DyLight 750 dye and characterization was done using near-infrared optical imaging. A main disadvantage with optical imaging is its lower sensitivity because of the high photon absorption by tissues. This makes the technique more suitable for image guided diagnosis or surgery but does not permit exact quantification of uptake in different tissues i.e., it is semi-quantitative $(33,48)$. On the other hand, the use of radioactive labels enables more sensitive tracking of the studied constructs and accurate quantification of tissue distribution. Therefore, our affitoxin variants were labelled with the radiometal ${ }^{111}$ In to permit exact measurement of the biodistribution. We expect that after internalization, the internalized radiometal accumulates inside the cells i.e., residualises. This would allow estimation of the affitoxin amounts internalized by different tissues. Kobayashi and co-workers have earlier compared the biodistribution of the anti-Tac(Fv)-PE38 immunotoxin labelled with ${ }^{111}$ In (residualizing) or I (non-residualizing) (49). They observed significant differences in uptake of the immunotoxin in the tissues that internalize it (liver and kidneys) with different labels. The biodistribution of ${ }^{125} \mathrm{I}$-labeled anti-Tac(Fv)-PE38 showed low renal accumulation of the immunotoxin. However, the biodistribution of the ${ }^{111}$ In-labeled variant suggests that the critical organ of anti-Tac(Fv)-PE38 toxicity should be the kidney. They finally concluded that in the case of a radiolabelled PE38-fused immunotoxin, ${ }^{111} \mathrm{In}$ is a more appropriate label to reflect conjugate delivery to tissue.

All three constructs were efficiently labelled with ${ }^{111} \mathrm{In}$ using the CHX-A"-DTPA chelator under the selected labelling conditions with high stability of the radiolabel. The three conjugates were capable of specific binding to HER2-expressing cells, indicating no apparent influence on the binding capacity of the affitoxins to HER2 after labelling (Fig. 1).

Interestingly, the novel constructs containing the HEHEHE-tag demonstrated more rapid internalization by 
SKOV-3 cells in comparison with the $\mathrm{H}_{6}$-tag containing variant developed by Zelienski and co-workers and the parental Affibody molecule DOTA-Z $Z_{\text {HER 2:342 }}$ (45) (Fig. 2). Part of the explanation can likely be attributed to the noticeable modifications on both its N- (incorporation of the HEHEHE-tag) and $\mathrm{C}$ - (the use of modified PE38X8 derivative) termini in comparison with $\mathrm{H}_{6}-\mathrm{Z}_{\mathrm{HER} 2}-\mathrm{PE} 38$ and DOTA-Z $\mathrm{HER}_{2: 342}$. These changes influence the overall structure and the local charge concentration of the affitoxin, which might interfere in different ways with Affitoxin-HER2 receptor interaction. We have earlier observed similar effects on the internalization rate when Affibody molecules were modified using different chelating moieties and even when the same chelator was used for labelling Affibody molecules with different radionuclides $(47,50)$. Regardless of the underlying reasons, the higher internalization (rate and total amount) of the HEHEHE-containing constructs may improve efficacy of cancer treatment because of enhanced delivery of toxins inside the malignant cells. The measured affinity of ${ }^{111}$ In-labeled- (HE) ${ }_{3}-Z_{\mathrm{HER} 2}-\mathrm{ABD}-\mathrm{PE} 38 \mathrm{X} 8$ and $(\mathrm{HE})_{3}-\mathrm{Z}_{\mathrm{HER} 2}-\mathrm{ABD}-\mathrm{PE} 38 \mathrm{X} 8$ to the HER2-receptor on cells was in the low nanomolar range and in agreement with previously reported data for the same conjugates (Fig. 3) (10). This demonstrates no alteration of the constructs' affinity by radiolabelling. An interesting finding from the LigandTracer experiment was that the interaction of the new conjugates with SKOV-3 cells most resembled a 1:2 interaction. Earlier we have found that binding of anti-HER2 Affibody molecules to HER2-expressing cell lines in vitro is influenced by the interaction of the target receptors with other co-expressed HER family receptors (51). The change in receptor conformation due to heterodimerization might result in weaker interactions of the affitoxin with a sub-set of the receptor molecules, which would lead to that the 1:2 model best describes the affitoxin/ SKOV3 interaction. A biosensor analysis of the interaction between the affitoxins and the HER 2 receptor alone, lacking dimerization partners, shows that the interaction follows a 1:1 model.

The substitution of the hexahistidine-tag in ${ }^{111} \mathrm{In}^{-\mathrm{H}_{6}}$ $\mathrm{Z}_{\mathrm{HER} 2}$-PE38 with the more hydrophilic HEHEHE-tag in ${ }^{111} \mathrm{In}-(\mathrm{HE})_{3}-\mathrm{Z}_{\mathrm{HER} 2}-\mathrm{PE} 38 \mathrm{X} 8$ reduced the liver uptake by almost $20 \%$ (from $19.9 \pm 1.8$ to $16.2 \pm 0.8 \% \mathrm{ID} / \mathrm{g}$, at $4 \mathrm{~h}$ after injection (Fig. 4). This is in agreement with our previous results (43). Despite the reduction in hepatic uptake achieved by $(\mathrm{HE})_{3-}$ $\mathrm{Z}_{\mathrm{HER} 2}-\mathrm{PE} 38 \mathrm{X} 8$, the liver accumulated radioactivity remains high compared to non-toxin fused Affibody molecules (43). This indicates that the mechanism of uptake of the affitoxin in liver is mainly driven by the PE38X8-part. This assumption is supported by studies involving the anti-Tac Fv fragment targeting the interleukin-2-receptor (IL-2R $\alpha$ pr Tac) $(49,52)$. When the anti-Tac Fv fragment was conjugated to PE38, liver uptake increased several-fold compared to the non-toxin fused fragment $(12.42 \pm 0.58$ vs. $3.4 \pm 0.7 \% \mathrm{ID} / \mathrm{g} 15 \mathrm{~min}$ after injection for ${ }^{125} \mathrm{I}$-anti-Tac-Fv-PE38 and ${ }^{125} \mathrm{I}$-anti-Tac-dsFv respectively). In this study, the reduction in hepatic uptake of the HEHEHE-tag containing construct was accompanied with a significantly increased renal uptake. After glomerular filtration, it is likely that the radiolabelled affitoxin will be reabsorbed by the proximal tubular cells where it will be prone to enzymatic degradation $(49,53)$. This catabolic process may lead to the conversion of PE38X8 to a less toxic molecule. This may have a positive impact on the maximum tolerated dose of the affitoxin that can be injected without toxic implications.

In order to extend the plasma half-life of the affitoxin, we fused it with albumin-binding domain (ABD). The results from the comparative biodistribution study between the ABD- and non-ABD-fused affitoxins demonstrated a clear effect on the half-life when the affitoxin was conjugated to ABD (Table I). The retention of ${ }^{111} \mathrm{In}-(\mathrm{HE})_{3}-\mathrm{Z}_{\mathrm{HER} 2}-\mathrm{ABD}-\mathrm{PE} 38 \mathrm{X} 8$ in the blood was on average 28 -fold higher than that of ${ }^{111} \mathrm{In}-(\mathrm{HE})_{3}-\mathrm{Z}_{\mathrm{HER}^{-}}$ PE38X8. A surprising finding of this study is the more rapid blood clearance of ${ }^{111} \mathrm{In}-(\mathrm{HE})_{3}-\mathrm{Z}_{\mathrm{HER} 2}$-ABD-PE38X8 in comparison to previously studied ABD-fused Affibody molecules $(35,36)$. Interestingly ${ }^{111} \mathrm{In}-(\mathrm{HE})_{3}-\mathrm{Z}_{\mathrm{HER} 2}-\mathrm{ABD}-\mathrm{PE} 38 \mathrm{X} 8$ showed also several-fold higher accumulation in the liver compared to other ABD-fused Affibody molecules $(35,36)$. The main difference between these fusion-molecules is the presence of the toxin PE38X8. As pointed out earlier, we expect that the elevated hepatic uptake is mainly a toxin-dependent effect. Therefore, it would be reasonable to assume that the more rapid clearance of the $\mathrm{ABD}$-fused affitoxin from circulation is due to accumulation and trapping of the toxin-conjugate by the hepatocytes. As a result of longer retention in blood, ${ }^{111} \mathrm{In}-(\mathrm{HE})_{3}-\mathrm{Z}_{\mathrm{HER} 2}-\mathrm{ABD}-\mathrm{PE} 38 \mathrm{X} 8$ showed $>5$-fold reduced renal accumulation in comparison with ${ }^{111} \mathrm{In}-(\mathrm{HE})_{3}-\mathrm{Z}_{\mathrm{HER} 2}-\mathrm{PE} 38 \mathrm{X} 8$. The higher renal excretion of ${ }^{111} \mathrm{In}-(\mathrm{HE})_{3}-\mathrm{Z}_{\mathrm{HER} 2}-\mathrm{PE} 38 \mathrm{X} 8$ may explain the significantly lower accumulation of this construct in the liver.

${ }^{111}$ In- $(\mathrm{HE})_{3}-\mathrm{Z}_{\mathrm{HER} 2}-\mathrm{ABD}-\mathrm{PE} 38 \mathrm{X} 8$ targeted HER 2expressing xenografts in mice specifically (Fig. 6). The uptake of the radiolabelled control fusion toxin ${ }^{111} \mathrm{In}-(\mathrm{HE})_{3}-\mathrm{Z}_{\mathrm{taq}}-\mathrm{ABD}-$ PE38X8 in the xenografted tumour was significantly $(\mathrm{p}<0.05)$ lower than the uptake of the HER2-binding construct. The uptake of the HER2-affitoxin (HE) ${ }_{3}-\mathrm{Z}_{\mathrm{HER} 2}-\mathrm{ABD}-\mathrm{PE} 38 \mathrm{X} 8$ in the tumour $(5.5 \pm 1 \% \mathrm{ID} / \mathrm{g}$ at $24 \mathrm{~h}$ after injection) was lower in comparison to the parental HER2-Affibody $\mathrm{Z}_{\mathrm{HER} 2: 2891}$ (11 $\pm 4 \% \mathrm{ID} / \mathrm{g}$ at $24 \mathrm{~h}$ after injection) (54). A similar difference was reported by Zilienski et al (9). They observed a noneven distribution of the affitoxin, $\mathrm{H}_{6}-\mathrm{Z}_{\mathrm{HER} 2}$-PE38 in BT-474 xenografts (with high HER2-expression), in comparison with non-toxin fused $\mathrm{Z}_{\mathrm{HER} 2}$ Affibody molecules. They attributed this to the large size of the affitoxin, which decreases the ability of the construct to diffuse deep into the tumour tissue. However, this size effect was more profound in xenografts with larger volumes, while tumours with relatively small sizes responded efficaciously to the HER2-Affitoxin treatment. It would be expected that the even bigger construct $(\mathrm{HE})_{3}-\mathrm{Z}_{\mathrm{HER}^{-}}$ ABD-PE38X8, associated with the serum albumin will have a relatively lower tumour penetration when compared to the parental $\mathrm{Z}_{\mathrm{HER} 2}$ Affibody molecule. Together this may explain the relatively lower tumour accumulation of $(\mathrm{HE})_{3}-\mathrm{Z}_{\mathrm{HER} 2}-\mathrm{ABD}-$ PE38X8. It has to be noted, that $(\mathrm{HE})_{3}-\mathrm{Z}_{\mathrm{HER} 2}-\mathrm{ABD}-\mathrm{PE} 38 \mathrm{X} 8$ adduct to albumin would still have a smaller size compared to a full $\mathrm{IgG} \mathrm{mAb}$ and thus would have better tissue penetration.

In the toxicity experiment, one mouse in the group $(n=6)$ injected with the highest dose of $(\mathrm{HE})_{3}-\mathrm{Z}_{\mathrm{HER} 2}-\mathrm{ABD}-\mathrm{PE} 38 \mathrm{X} 8$ had a critical loss of weight and was terminated. Other mice in this group had a significant reduction in the average weight, but recovered successfully and survived until termination of the study (Fig. 7). When mice were injected with lower doses $(0.275$ and $0.1375 \mathrm{mg} / \mathrm{kg}$, equivalent doses providing a 
clear therapeutic effect in the study reported by Zielinski and co-workers (9), mice did not experience significant weight loss during the study and did not show any other signs of toxicity.

In conclusion, the use of the HEHEHE-tag on the $\mathrm{N}$-terminal end of the affitoxin molecule reduced hepatic uptake, however the effect was relatively small, presumably due to the presence of PE38X8. Fusion to the ABD is associated with longer residence in circulation and would permit less frequent injections of the affitoxins. The novel tripartite fusion toxin $(\mathrm{HE})_{3}-\mathrm{Z}_{\mathrm{HER} 2}-\mathrm{ABD}-\mathrm{PE} 38 \mathrm{X} 8$ is capable of specific targeting of HER2-expressing xenografts in vivo. Multiple injections of therapeutic doses of $(\mathrm{HE})_{3}-\mathrm{Z}_{\mathrm{HER} 2}-\mathrm{ABD}-\mathrm{PE} 38 \mathrm{X} 8$ had no significant side effects. The results of this study emphasize the importance of careful design to improve the properties of therapeutic agents.

\section{Acknowledgements}

This study was supported by grants from the Swedish Research Council (Vetenskapsrådet) and the Swedish Cancer Society (Cancerfonden). The authors express their gratitude to Mrs. Christina Atterby for her assistance in biodistribution studies.

\section{References}

1. Pohlmann PR, Mayer IA and Mernaugh R: Resistance to trastuzumab in breast cancer. Clin Cancer Res 15: 7479-7491, 2009.

2. Holohan C, Van Schaeybroeck S, Longley DB and Johnston PG: Cancer drug resistance: An evolving paradigm. Nat Rev Cancer 13: 714-726, 2013.

3. Rosenzweig SA: Acquired resistance to drugs targeting receptor tyrosine kinases. Biochem Pharmacol 83: 1041-1048, 2012.

4. Kim EG and Kim KM: Strategies and advancement in antibodydrug conjugate optimization for targeted cancer therapeutics. Biomol Ther (Seoul) 23: 493-509, 2015.

5. Kreitman RJ: Recombinant immunotoxins containing truncated bacterial toxins for the treatment of hematologic malignancies. BioDrugs 23: 1-13, 2009.

6. Alewine C, Hassan R and Pastan I: Advances in anticancer immunotoxin therapy. Oncologist 20: 176-185, 2015.

7. Martin-Killias P, Stefan N, Rothschild S, Plückthun A and Zangemeister-Wittke U: A novel fusion toxin derived from an EpCAM-specific designed ankyrin repeat protein has potent antitumor activity. Clin Cancer Res 17: 100-110, 2011.

8. Zielinski R, Lyakhov I, Jacobs A, Chertov O, Kramer-Marek G, Francella N, Stephen A, Fisher R, Blumenthal R and Capala J: Affitoxin - a novel recombinant, HER2-specific, anticancer agent for targeted therapy of HER2-positive tumors. J Immunother 32: 817-825, 2009.

9. Zielinski R, Lyakhov I, Hassan M, Kuban M, Shafer-Weaver K, Gandjbakhche A and Capala J: HER2-affitoxin: A potent therapeutic agent for the treatment of HER2-overexpressing tumors. Clin Cancer Res 17: 5071-5081, 2011.

10. Liu H, Seijsing J, Frejd FY, Tolmachev V and Gräslund T: Target-specific cytotoxic effects on HER2-expressing cells by the tripartite fusion toxin ZHER2:2891-ABD-PE38X8, including a targeting affibody molecule and a half-life extension domain. Int J Oncol 47: 601-609, 2015.

11. Mazor R, Vassall AN, Eberle JA, Beers R, Weldon JE, Venzon DJ, Tsang KY, Benhar I and Pastan I: Identification and elimination of an immunodominant T-cell epitope in recombinant immunotoxins based on Pseudomonas exotoxin A. Proc Natl Acad Sci USA 109: E3597-E3603, 2012.

12. Onda M, Beers R, Xiang L, Nagata S, Wang Q-C and Pastan I: An immunotoxin with greatly reduced immunogenicity by identification and removal of B cell epitopes. Proc Natl Acad Sci USA 105: 11311-11316, 2008

13. Liu W, Onda M, Lee B, Kreitman RJ, Hassan R, Xiang L and Pastan I: Recombinant immunotoxin engineered for low immunogenicity and antigenicity by identifying and silencing human B-cell epitopes. Proc Natl Acad Sci USA 109: 11782-11787, 2012.
14. Onda M, Beers R, Xiang L, Lee B, Weldon JE, Kreitman RJ and Pastan I: Recombinant immunotoxin against B-cell malignancies with no immunogenicity in mice by removal of B-cell epitopes. Proc Natl Acad Sci USA 108: 5742-5747, 2011

15. King C, Garza EN, Mazor R, Linehan JL, Pastan I, Pepper M and Baker D: Removing T-cell epitopes with computational protein design. Proc Natl Acad Sci USA 111: 8577-8582, 2014.

16. Vuhai-Luuthi MT, Jolivet A, Jallal B, Salesse R, Bidart JM, Houllier A, Guiochon-Mantel A, Garnier J and Milgrom E: Monoclonal antibodies against luteinizing hormone receptor. Immunochemical characterization of the receptor. Endocrinology 127: 2090-2098, 1990.

17. Reiter Y, Brinkmann U, Jung SH, Lee B, Kasprzyk PG, King CR and Pastan I: Improved binding and antitumor activity of a recombinant anti-erbB2 immunotoxin by disulfide stabilization of the Fv fragment. J Biol Chem 269: 18327-18331, 1994.

18. Bera TK, Viner J, Brinkmann E and Pastan I: Pharmacokinetics and antitumor activity of a bivalent disulfide-stabilized Fv immunotoxin with improved antigen binding to erbB2. Cancer Res 59: 4018-4022, 1999.

19. Schmidt M, McWatters A, White RA, Groner B, Wels W, Fan Z and Bast RC Jr: Synergistic interaction between an anti-p185HER-2 pseudomonas exotoxin fusion protein [ $\mathrm{scFv}(\mathrm{FRP} 5)-\mathrm{ETA}]$ and ionizing radiation for inhibiting growth of ovarian cancer cells that overexpress HER-2. Gynecol Oncol 80: 145-155, 2001.

20. Wang L, Liu B, Schmidt M, Lu Y, Wels W and Fan Z: Antitumor effect of an HER2-specific antibody-toxin fusion protein on human prostate cancer cells. Prostate 47: 21-28, 2001.

21. Shinohara H, Morita S, Kawai M, Miyamoto A, Sonoda T, Pastan I and Tanigawa N: Expression of HER2 in human gastric cancer cells directly correlates with antitumor activity of a recombinant disulfide-stabilized anti-HER2 immunotoxin. J Surg Res 102: 169-177, 2002.

22. Kreitman RJ, Wilson WH, Bergeron K, Raggio M, StetlerStevenson M, FitzGerald DJ and Pastan I: Efficacy of the anti-CD22 recombinant immunotoxin BL22 in chemotherapyresistant hairy-cell leukemia. N Engl J Med 345: 241-247, 2001.

23. Thurber GM, Schmidt MM and Wittrup KD: Antibody tumor penetration: Transport opposed by systemic and antigen-mediated clearance. Adv Drug Deliv Rev 60: 1421-1434, 2008.

24. Löfblom J, Feldwisch J, Tolmachev V, Carlsson J, Ståhl S and Frejd FY: Affibody molecules: Engineered proteins for therapeutic, diagnostic and biotechnological applications. FEBS Lett 584: 2670-2680, 2010

25. Orlova A, Magnusson M, Eriksson TLJ, Nilsson M, Larsson B, Höidén-Guthenberg I, Widström C, Carlsson J, Tolmachev V, Ståhl S, et al: Tumor imaging using a picomolar affinity HER2 binding affibody molecule. Cancer Res 66: 4339-4348, 2006.

26. Tolmachev V, Rosik D, Wållberg H, Sjöberg A, Sandström M, Hansson M, Wennborg A and Orlova A: Imaging of EGFR expression in murine xenografts using site-specifically labelled anti-EGFR ${ }^{111}$ In-DOTA-Z EGFR:2377 Affibody molecule: aspect of the injected tracer amount. Eur J Nucl Med Mol Imaging 37: 613-622, 2010 .

27. Tolmachev V, Malmberg J, Hofström C, Abrahmsén L, Bergman T, Sjöberg A, Sandström M, Gräslund T and Orlova A: Imaging of insulinlike growth factor type 1 receptor in prostate cancer xenografts using the affibody molecule ${ }^{111}$ In-DOTAZIGF1R:4551. J Nucl Med 53: 90-97, 2012.

28. Tolmachev V, Varasteh Z, Honarvar H, Hosseinimehr SJ, Eriksson O, Jonasson P, Frejd FY, Abrahmsen L and Orlova A: Imaging of platelet-derived growth factor receptor $\beta$ expression in glioblastoma xenografts using affibody molecule ${ }^{111}$ In-DOTAZ09591. J Nucl Med 55: 294-300, 2014.

29. Orlova A, Malm M, Rosestedt M, Varasteh Z, Andersson K, Selvaraju RK, Altai M, Honarvar H, Strand J, Ståhl S, et al: Imaging of HER3-expressing xenografts in mice using a $(99 \mathrm{~m})$ Tc(CO) 3-HEHEHE-Z HER3:08699 affibody molecule. Eur J Nucl Med Mol Imaging 41: 1450-1459, 2014.

30. Kramer-Marek G, Shenoy N, Seidel J, Griffiths GL, Choyke P and Capala J: 68Ga-DOTA-affibody molecule for in vivo assessment of HER2/neu expression with PET. Eur J Nucl Med Mol Imaging 38: 1967-1976, 2011.

31. Orlova A, Wållberg H, Stone-Elander S and Tolmachev V: On the selection of a tracer for PET imaging of HER2-expressing tumors: Direct comparison of a 124I-labeled affibody molecule and trastuzumab in a murine xenograft model. J Nucl Med 50: 417-425, 2009. 
32. Heskamp S, Laverman P, Rosik D, Boschetti F, van der Graaf WT, Oyen WJ, van Laarhoven HW, Tolmachev V and Boerman OC: Imaging of human epidermal growth factor receptor type 2 expression with 18F-labeled affibody molecule ZHER2:2395 in a mouse model for ovarian cancer. J Nucl Med 53: 146-153, 2012.

33. Lee SB, Hassan M, Fisher R, Chertov O, Chernomordik V, Kramer-Marek G, Gandjbakhche A and Capala J: Affibody molecules for in vivo characterization of HER2-positive tumors by near-infrared imaging. Clin Cancer Res 14: 3840-3849, 2008.

34. Lundberg E, Höidén-Guthenberg I, Larsson B, Uhlén M and Gräslund T: Site-specifically conjugated anti-HER2 Affibody molecules as one-step reagents for target expression analyses on cells and xenograft samples. J Immunol Methods 319: 53-63, 2007.

35. Tolmachev V, Orlova A, Pehrson R, Galli J, Baastrup B, Andersson K, Sandström M, Rosik D, Carlsson J, Lundqvist H, et al: Radionuclide therapy of HER2-positive microxenografts using a 177Lu-labeled HER2-specific Affibody molecule. Cancer Res 67: 2773-2782, 2007.

36. Orlova A, Jonsson A, Rosik D, Lundqvist H, Lindborg M, Abrahmsen L, Ekblad C, Frejd FY and Tolmachev V: Sitespecific radiometal labeling and improved biodistribution using ABY-027, a novel HER2-targeting affibody molecule-albuminbinding domain fusion protein. J Nucl Med 54: 961-968, 2013.

37. Altai M, Wållberg H, Honarvar H, Strand J, Orlova A, Varasteh Z, Sandström M, Löfblom J, Larsson E, Strand SE, et al: 188Re-ZHER2:V2, a promising affibody-based targeting agent against HER2-expressing tumors: preclinical assessment. J Nucl Med 55: 1842-1848, 2014.

38. Sörensen J, Sandberg D, Sandström M, Wennborg A, Feldwisch J, Tolmachev V, Åström G, Lubberink M, Garske-Román U, Carlsson J, et al: First-in-human molecular imaging of HER2 expression in breast cancer metastases using the ${ }^{111}$ In-ABY-025 affibody molecule. J Nucl Med 55: 730-735, 2014.

39. Sörensen J, Velikyan I, Sandberg D, Wennborg A, Feldwisch J, Tolmachev V, Orlova A, Sandström M, Lubberink M, Olofsson H, et al: Measuring HER2-receptor expression in metastatic breast cancer using [(68)Ga]ABY-025 Affibody PET/CT. Theranostics 6: 262-271, 2016 .

40. Makrides SC, Nygren PA, Andrews B, Ford PJ, Evans KS, Hayman EG, Adari H, Uhlén M and Toth CA: Extended in vivo half-life of human soluble complement receptor type 1 fused to a serum albumin-binding receptor. J Pharmacol Exp Ther 277: 534-542, 1996

41. Andersen JT, Pehrson R, Tolmachev V, Daba MB, Abrahmsén L and Ekblad C: Extending half-life by indirect targeting of the neonatal $\mathrm{Fc}$ receptor $(\mathrm{FcRn})$ using a minimal albumin binding domain. J Biol Chem 286: 5234-5241, 2011

42. Jonsson A, Dogan J, Herne N, Abrahmsén L and Nygren P-A: Engineering of a femtomolar affinity binding protein to human serum albumin. Protein Eng Des Sel 21: 515-527, 2008.

43. Tolmachev V, Hofström C, Malmberg J, Ahlgren S, Hosseinimehr SJ, Sandström M, Abrahmsén L, Orlova A and Gräslund T: HEHEHE-tagged affibody molecule may be purified by IMAC, is conveniently labeled with [99(m) Tc(CO)3](+), and shows improved biodistribution with reduced hepatic radioactivity accumulation. Bioconjug Chem 21: 2013-2022, 2010.
44. Orlova A, Rosik D, Sandström M, Lundqvist H, Einarsson L and Tolmachev V: Evaluation of [(111/114m)In]CHX-A"-DTPAZHER 2:342, an affibody ligand coniugate for targeting of HER2-expressing malignant tumors. Q J Nucl Med Mol Imaging 51: 314-323, 2007.

45. Wållberg H and Orlova A: Slow internalization of anti-HER2 synthetic affibody monomer 111In-DOTA-ZHER2:342-pep2: implications for development of labeled tracers. Cancer Biother Radiopharm 23: 435-442, 2008.

46. Varasteh Z and Orlova A: Comparing the measured affinity of ${ }^{111}$ In-labeled ligands for cellular receptors by monitoring gamma, beta, or X-ray radiation with three different LigandTracer ${ }^{\circledR}$ devices. J Radioanal Nucl Chem 304: 823-828, 2015.

47. Altai M, Strand J, Rosik D, Selvaraju RK, Eriksson Karlström A, Orlova A and Tolmachev V: Influence of nuclides and chelators on imaging using affibody molecules: Comparative evaluation of recombinant affibody molecules site-specifically labeled with $68 \mathrm{Ga}$ and ${ }^{111} \mathrm{In}$ via maleimido derivatives of DOTA and NODAGA. Bioconjug Chem 24: 1102-1109, 2013.

48. Gong $\mathrm{H}$, Kovar J, Little $\mathrm{G}$, Chen $\mathrm{H}$ and Olive DM: In vivo imaging of xenograft tumors using an epidermal growth factor receptor-specific affibody molecule labeled with a near-infrared fluorophore. Neoplasia 12: 139-149, 2010.

49. Kobayashi H, Kao CH, Kreitman RJ, Le N, Kim MK, Brechbiel MW, Paik CH, Pastan I and Carrasquillo JA: Pharmacokinetics of ${ }^{111} \mathrm{In}$ - and ${ }^{125}$ I-labeled antiTac single-chain Fv recombinant immunotoxin. J Nucl Med 41: 755-762, 2000.

50. Tolmachev V, Velikyan I, Sandström M and Orlova A: A HER2binding Affibody molecule labelled with 68Ga for PET imaging: Direct in vivo comparison with the ${ }^{111}$ In-labelled analogue. Eur J Nucl Med Mol Imaging 37: 1356-1367, 2010.

51. Barta P, Malmberg J, Melicharova L, Strandgård J, Orlova A, Tolmachev V, Laznicek M and Andersson K: Protein interactions with HER-family receptors can have different characteristics depending on the hosting cell line. Int J Oncol 40: 1677-1682, 2012.

52. Kobayashi H, Yoo TM, Kim IS, Kim MK, Le N, Webber KO, Pastan I, Paik CH, Eckelman WC and Carrasquillo JA: L-lysine effectively blocks renal uptake of ${ }^{125} \mathrm{I}$ - or $99 \mathrm{mTc}$-labeled anti-Tac disulfide-stabilized Fv fragment. Cancer Res 56: 3788-3795, 1996.

53. Altai M, Varasteh Z, Andersson K, Eek A, Boerman O and Orlova A: In vivo and in vitro studies on renal uptake of radiolabeled affibody molecules for imaging of HER2 expression in tumors. Cancer Biother Radiopharm 28: 187-195, 2013.

54. Ahlgren S, Orlova A, Wållberg H, Hansson M, Sandström M, Lewsley R, Wennborg A, Abrahmsén L, Tolmachev V and Feldwisch J: Targeting of HER2-expressing tumors using ${ }^{111}$ In-ABY-025, a second-generation affibody molecule with a fundamentally reengineered scaffold. J Nucl Med 51: 1131-1138, 2010. 